\title{
The morphological variation and systematic value of stamen pairs in the Magnoliatae
}

\author{
With 26 Figures and one Table
}

\section{Summary}

The distribution of paired stamens has been investigated in the Magnoliatae. Stamens can be inserted in pairs as the result of two developmental processes: (a) spatial shifts in the flower caused by the transition of a spiral into a cyclic arrangement of floral parts or (b) dédoublement of complex primordia. The first case is linked with a progressive loss of stamen whorls, ultimately leading to the replacement of all pairs by single stamens. Outer paired stamens are characteristic for polycyclic androecia and are often retained when the upper stamen whorls vanish. The outer pairs may be replaced by petals in some cases or by single stamens in other. The second situation arises by the splitting of complex primordia in two secondary primordia or by the independent initiation of the stamens of a pair. Replacement of single stamens by pairs reflects an increase in the pollination potential and has arisen several times, mainly in relation with oligomerous androecia.

The distribution of these two types of stamen pairs on a Dahlgrenogram confirms the existence of two groups. These groups correspond more or less with the presence of the characters polymery and oligomery, proposed by RONSE DECRAENE \& SMETS $(1987,1993 \mathrm{~b}$, 1995b).

\section{Introduction}

In the majority of angiosperms the stamens occupy a fixed position in the flower, it be opposite a petal, sepal or tepal. This position is the result of a given sequence of initiation, that can be

\section{Zusammenfassung}

Die Verbreitung von Staubblattpaaren wurde in den Magnoliatae untersucht. Staubblattpaare können sich nach zwei verschiedenen Entwicklungsmustern herausbilden: (a) ther Verschiebungen in der Blüte durch Transformation von spiraliger zu zyklischer Insertion von Blütenorganen und (b) durch Dédoublement komplexer Primordien.

Die erstere Möglichkeit hängt mit einem fortschreitenden Verlust von Staubblattwirteln zusammen und endet mit dem Wechsel von paarigen zu einfachen Staubblättern. Die paarweise Anordnung der äußeren Staubblätter kennzeichnet polyzyklische Androeceen und ist häufig dann vorhanden, wenn die höheren Staubblattkreise verschwinden. Die äußeren Paare können manchmal durch Petalen oder durch einzelne Staubblätter ersetzt werden. Die zweite Möglichkeit ergibt sich durch Teilung eines komplexen Primordiums in zwei sekundäre Primordien oder durch die unabhängige Anlage der Stamen eines Paares. Der Ersatz von einfachen Staubblättern durch Paare ermöglicht die Erhöhung des Pollinationspotentials und ist mehrfach entstanden, hauptsächlich in Verbindung mit Oligomerie der Androeceen.

Die Darstellung dieser zwei Typen von Staubblattpaaren auf einem Dahlgrenogramm zeigt die Existenz von zwei Gruppen, die in etwa mit den von RoNSE DECRAENE \& SMETS $(1987,1993$ b, 1995b) vorgeschlagenen Merkmalen Polymerie und Oligomerie übereinstimmen.

whorled (cyclic,) spiral (helical) or unordered (chaotic). However, in some cases two stamens take up a position where only a single organ is expected. This odd situation received the occasional attention of systematists working on specific groups, but has not been approached on a 
larger scale englobing the whole of the Magnoliatae. Indeed, the presence of paired stamens tends to be more widespread than expected and necessitates a more detailed analysis.

ENDRESS $(1987,1992,1994)$ interpreted cases with stamen pairs as the result of doubling (dédoublement). This duplication may happen at the transition from one organ category to another (e.g. perianth-stamens) or within an organ category when numerous whorls are present. For example, in flowers with many stamens arranged in whorls, there may be an alternation of whorls with a doubled and halved number of stamens (e.g. Papaveraceae, Annonaceae). On the other hand, ERBAR \& LEINS $(1981,1983,1994)$ have demonstrated that stamens arranged as outer pairs can be the result of the transition of a spiral flower into a trimerous whorled flower. They attached a particular importance to a paired arrangement of the first six stamens as a basic step in the phylogeny of the angiosperms, in suggesting a relationship between Annonaceae, Aristolochiaceae and Alismataceae (see LEINS \& ERBAR 1985; ERBAR \& LEINS 1994). We have also demonstrated the importance of outer stamen pairs in discussing the distribution of different androecial configurations (see RONSE DECRAENE \& SMETS 1993b).

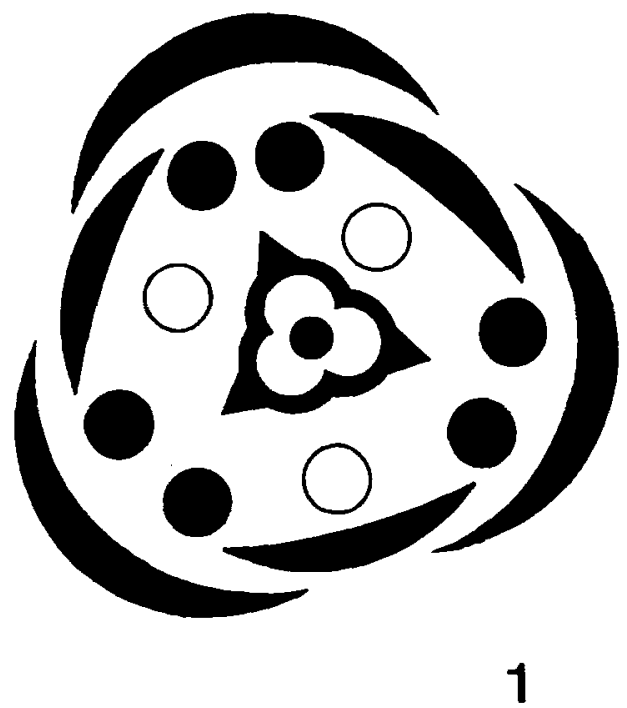

Two situations may look absolutely similar, as shown on Figs. 1 and 2. The first case represents a floral diagram of Rheum (Polygonaceae) with three inner stamens and six outer stamens in three pairs. The second figure represents the floral diagram of Peganum harmala (Zygophyllaceae) with single antesepalous stamens and ten antepetalous stamens in five pairs (cf. RONSE DECRAENE et al. 1996). These two cases may be equivalent, viz. they arise in a similar fashion and give a similar paired arrangement, or they may arise along completely different pathways and be only superficially similar. Who knows at first sight? Therefore two questions have to be considered: Firstly, it is important to know the means by which stamens arise as pairs, i.e. whether they arise by a similar process or whether there are different ontogenetic pathways leading to "similar" configurations. Secondly, it is worth investigating whether stamen pairs have some systematic significance, as they may occur in certain groups and not in other. The present study aims to analyse these questions, referring to the character-classification of the androecium configurations that has been proposed by Ronse Decraene \& SMets $(1987,1993 \mathrm{~b}$, 1995b).

Figs. 1, 2

1 - Floral diagram of Rheum (Polygonaceae) with paired outer stamens (full circles) and single inner stamens (hollow circles). 2 - Floral diagram of Pegantum (Zygophyllaceae) with paired antepetalous stamens (full circles) and simple antesepalous stamens (hollow circles) 


\section{Observations and discussion}

Direct observations and a literature survey of several taxa of the Magnoliatae revealed the widespread occurrence of stamen pairs. However, there is strong evidence that the presence of paired stamens is not homologous in the Magnoliatae. A preliminary distinction can be made between paired stamens that arise by dédoublement (splitting) of a complex primordium and paired stamens that are the result of a spatial shift induced by a cyclisation process. However, this distinction is sometimes difficult to make without ontogenetic and anatomical observations (see also RONSE DECRAENE \& SMETS 1993a).

\section{Dédoublement}

The tendency of primordia to split is strong in the angiosperm flower. Especially for stamens this tendency may be expressed in the usual dithecal tetrasporangiate arrangement of the anthers or further subdivisions of anthers into polysporangiate stamens (e.g. ENDRESS \& STUMPF 1990). Examples exist with a more or less incomplete splitting of stamens in two (or more) sections, such as Dizygotheca and Plerandra (Araliaceae: BAILlon 1876), Adoxa (Adoxaceae: ERBAR 1994; Roels \& SMETS 1994), Corylus (Betulaceae: DUTAILly 1876) or Telfairia (Cucurbitaceae: BAILlON 1885). There is also a strong cohesiveness of the paired stamens, even in mature flowers. Dédoublement must be strictly separated from partition. The latter represents the division of a structure in two equal halves, as e.g. in Adoxa. By dédoublement a splitting gives two equal sections that are equivalent to the original structure.

Ronse DeCRAENE \& SMETS (1993a) briefly discussed the means by which stamens arise as pairs, either as a result of dédoublement, or by shifts of the stamen site initiation. It was proposed to restrict the term dédoublement to all cases where two stamens replace a single stamen by increase; this is fundamentally different from the situation with pairs arising as a result of spatial shifts.

Doubling of stamens can happen occasionally in any representative of a species, when two primordia occupy the position of a single primordium (Figs. 3-5). In Geranium endressii (Geraniaceae) one antesepalous stamen is occasionally

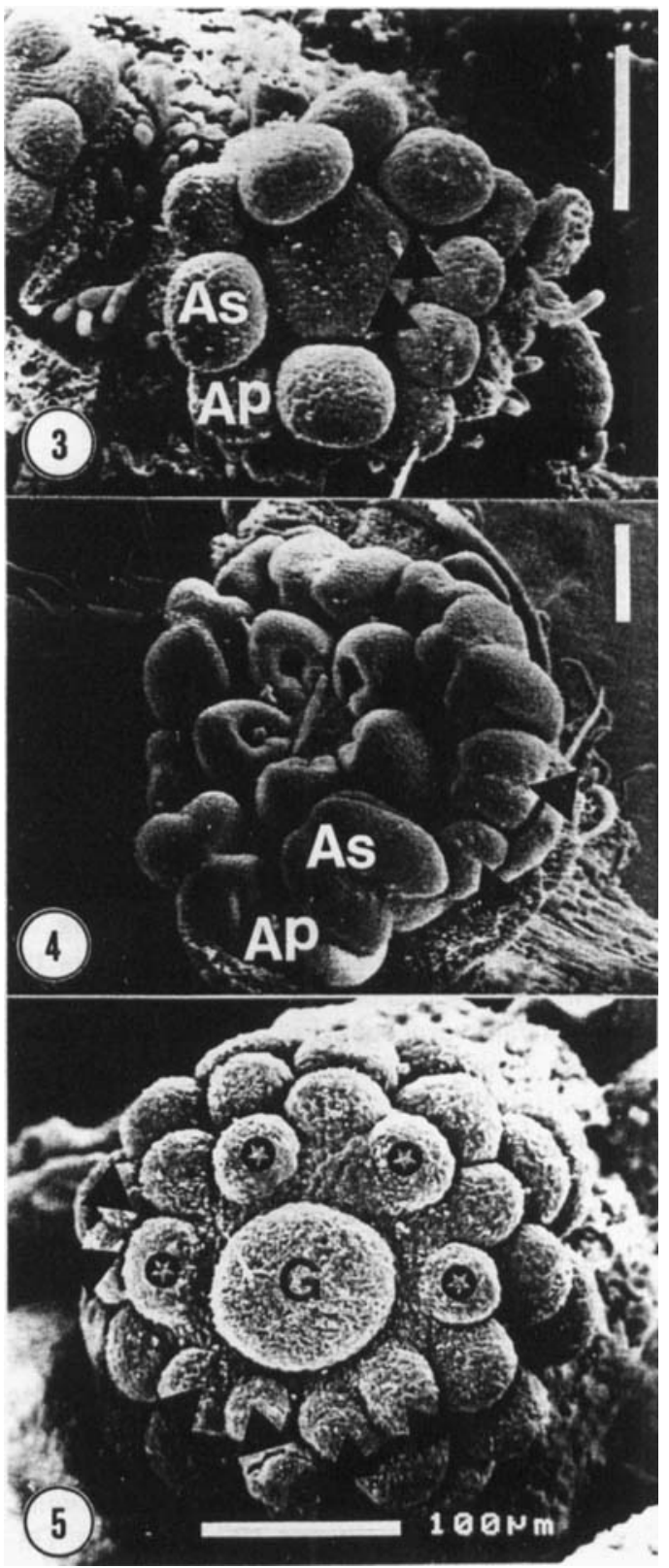

Figs. 3-5

Flower buds with occasional doubling of stamen primordia shown by black triangles

3 - Gerania endressii J. GAY (Geraniaceae) with one "doubled" antesepalous stamen. 4 - Choisya ternata H.B.K. (Rutaceae) with "doubled" antepetalous stamen. 5 - Macleaya condara R. BR. (Papaveraceae) showing three "doubled" primordia: the upper pseudowhorl has four "normal" (stars) and two "paired" stamens (black triangles); a lower whorl has one pair

Abbreviations: Ap - antepetalous stamen; As - antesepaious stamen; $\mathrm{G}$ - gynoecium; All scale bars $=100 \mu \mathrm{m}$ 
Figs. $6-13$

Examples of dédoublement of stamens

Figs. 6, 7 - Theobroma cacao L. (Sterculiaceae)

6-Flower with five complex antepetalous primordia (black triangle). 7 -Older bud; the complex primordium has split in two secondary primordia. Note the presence of antesepalous staminodes

Figs. 8, 9 - Peganum harmala L. (Zygophyilaceae)

8 - Independent inception of two primordia in antepetalous position (arrows), centrifugal to the antesepalous stamens. 9 - Older stage with inner antesepalous stamen (hollow circle) and outer antepetalous pair (full circles)

Fig. 10 - Chamaelaucium unicatum ScHAU. (Myrtaceae)

Bud with antepetallous triplets and single antesepalous stamens (not vissible), petals removed; note that the outer stamen pairs are staminodial

Fig. II - Nitraria retusa (AsCHERS.) ForSK. (Zygophyllaceae)

Complex haplostemonous androecium with stamens of an antesepalous triplet (full circles), differing in size from those of a neighbouring triplet (hollow circles)

Figs. 12, 13 - Aristotelia chilensis (MOL.) STUNTZ (Elaeocarpaceae)

12 - Apical view of young flower bud: note the arrangement of the stamens in triplets (full circles). differing in size from those of a neighbouring triplet (hollow circles). 13-Transverse section of the same, showing common supply for the petal and antepetalous ,pair" (arrows)

Abbreviations: As - antesepalous stamen; P - petal; S - sepal; St - staminodium. Scale bars $=100 \mu \mathrm{m}$. except Fig. $6=50 \mu \mathrm{m}$ and Fig. $13=200 \mu \mathrm{m}$

"doubled" (Fig. 3), while it is the antepetalous whorl in Choisya ternata (Rutaceae) (Fig. 4). Even in multistaminate androecia there is the occasional presence of odd pairs, as in Macleaya cordata (Papaveraceae) (Fig. 5). Such occasional increase is only an expression of the morphogenetic variability of flowers and has little systematic value.

Doubling becomes more important when it is present as a rule in all members of a species and arises along a fixed developmental pattern. In some cases the splitting of a complex primordium results in two equal parts (e.g. Theobroma cacao: Figs. 6, 7). More generally, no complex primordium is formed, but the paired stamens arise directly on the floral apex; two smaller primordia replace a single stamen without visible process of splitting (e.g. Peganum harmala: Ronse DeCRAENE \& SMETS 1993a; Ronse DeCRAENE et al. 1996; Figs. 8, 9). This phenomenon has often been described as "congenital dédoublement" in the past, but the term is misleading and inadequate to describe the process. As written elsewhere (RONSE DECRAENE \& SMETS 1993a; RONSE DECRAENE et al. 1996) we consider the difference between both modes of inception as relatively unimportant, because both conditions can be related to a variable pro- portion of growth (sensu TROLL 1956) related to a progressive alteration.

In the Rosaceae the outer stamens are usually built up as pairs. Many genera of the family have twenty stamens characteristically initiated in the following sequence: paired stamens opposite the sepals or between sepal and petal insertion, single stamens opposite the petals, and an inner whorl opposite the sepals again. In some cases only single stamens are present instead of pairs (e.g. Agrimonia, Stephanandra, Quillaja). Species with flowers having only antesepalous pairs are rare (e.g. Crataegus douglasii: Evans \& DiCKINSON 1993). The presence of the outer stamen pairs cannot be visualised as the splitting of an antepetalous or antesepalous stamen primordium, because they arise free from each other. The paired outer stamens may be a phylogenetically derived condition linked with a centripetal increase of stamens. However, LINDENHOFER \& WEBER (1995) had a different opinion about the occurrence of the outer stamen pairs of the Rosaceae. They believed the pairs and inner stamens to arise along a genetic spiral which follows the inception of the perianth. More research is needed to clarify this problem. It is worth mentioning that an initiation with paired outer stamens (or staminodes) similar to the Rosaceae characterizes the 


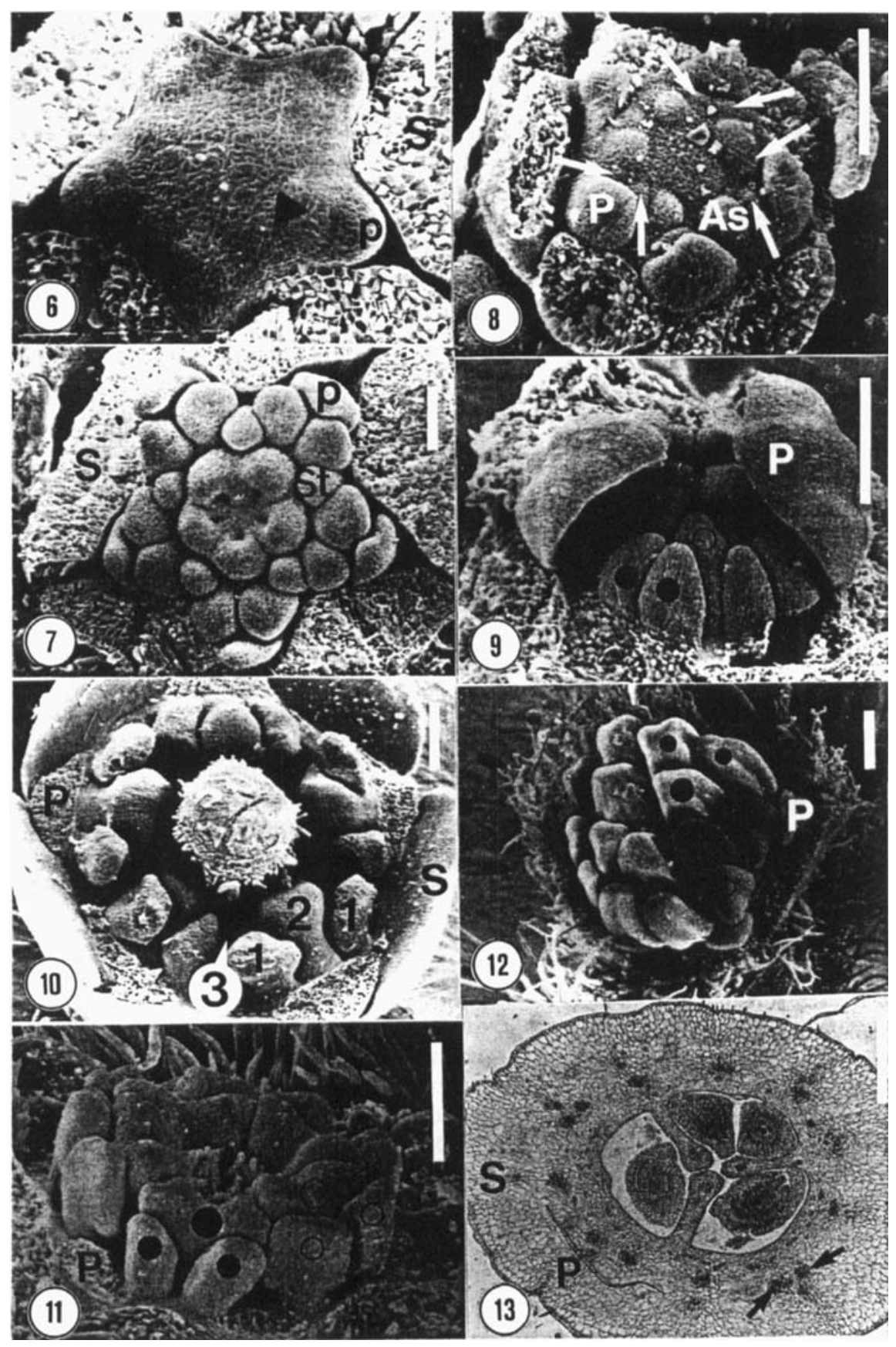


Myrtaceae which are basically diplostemonous (Fig. 10, Ronse Decraene \& SMETs 1991c).

Dédoublement of stamens is frequently linked with diplostemonous or obdiplostemonous flowers. In a pentamerous flower the total number of stamens is frequently fifteen (Table), because the antesepalous, or the antepetalous whorl consists of paired stamens. This conditions has often been overlooked and the androecium was incorrectly described by different authors as "made up of three cycles" (e.g. CRONQUIST 1981).

The interpretation of flowers with fifteen stamens can be problematic as it is sometimes very difficult to distinguish between cases with paired stamens and cases where two stamens are connected to a third centrally placed stamen (so-called triplets). Indeed, fifteen stamens can arise by at least four means in pentamerous flowers:

- the doubling of the antepetalous stamens; the antesepalous being unsplit [cf. (ob)diplostemony: Figs. 7-9];

- the doubling of the antesepalous stamens; the antepetalous being unsplit [cf. (ob)diplostemony];

- the trifurcation of the antepetalous stamens (cf. obhaplostemony);

- the trifurcation of the antesepalous stamens (cf. haplostemony: Figs. 11, 12).

In some instances it is almost impossible to distinguish between these four different means of increase, unless one studies both the floral anatomy and the floral ontogeny. This can be illustrated with following examples:

In Kirengeshoma palmata (Hydrangeaceae), stamens are situated in antesepalous triplets and arise in a latero-centripetal sequence. However, the stamen supply is not linked with a single antesepalous bundle splitting in three units. The antepetalous stamens are supplied by the splitting of a common petal-stamen bundle and the antesepalous traces by the division of common bundles running to sepal and stamen (cf. BENSEL \& PALSER 1975; KAPPELER 1995). In the related Hydrangeaceae there is a similar latero-centripetal increase of the antesepalous stamens (RONSE DECRAENE \& SMETS 1995b). In this example the vascular supply seems to be subordinated to the ontogeny.

Aristotelia chilensis (Elaeocarpaceae) has an androecium of fifteen stamens, with five antesepalous triplets (Fig. 12). Floral anatomy reveals the presence of a common trace to petal and antepetalous stamen pair and a single trace to the antesepalous stamen (Fig. 13). But can we attach much importance to the vascular connections, when all stamens seem to arise as antesepalous triplets? The outer stamens from different triplets also differ in size, but are of about equal size within their own triplet (Fig. 12). Here again one could see the vascular supply as an adaptation to the insertion of the stamens, without being evidence for an antepetalous position of the pairs.

In the Zygophyllaceae the vasculature and ontogeny are more concordant (RONSE DECRAENE \& SMETS 199la; Ronse DeCraene et al. 1996). Nitraria retusa has a haplostemonous androecium of fifteen stamens, arranged in antesepalous triplets (Fig. 11). This is confirmed from the vascular arrangements and the successive inception of the stamens of different triplets. Indeed, stamens of a so-called "antepetalous pair" may differ in size while the outer stamens of a given triplet are equivalent (Fig. 11; see RONSE DeCRAENE \& SMeTs 1991 a). In Peganum harma$l a$ of the same family the androecium is obdiplostemonous and the antepetalous stamens arise as pairs without connection to the more centrally placed antesepalous stamens (Figs. 8, 9; see RoNSE DECRAENE et al. 1996). The vasculature of the antepetalous stamens is connected with the petals as common traces. This is also visible as the development of neighbouring pairs may not be synchronous (Fig. 9). This demonstrates the difficulty in interpreting floral diagrams, which has often resulted in inaccurate descriptions, such as "stamens 15, uniseriate" (e.g. CRONQUIST 1981).

When stamens are situated in pairs, they are in most cases placed laterally of each other. However, in a few instances stamens are inserted on a radial row. This is the case of Hopea (Dipterocarpaceae) with 15 stamens. The stamens appear as three alternating whorls, but anatomically the antesepalous stamens (situated in a radial row) are linked through the division of a bundle (RAO 1962). Paired stamens in a radial row occur also in the Ebenaceae (Diospyros: BAILLON 1892) or Euphorbiaceae (Croton: NAIR \& ABRAHAM 1962).

Pairing may also be related to a reduction of stamens (cf. ENDRESS 1994): For example in Brownea ariza (Caesalpiniaceae) the median adaxial antepetalous stamen is replaced by a smaller pair (RONSE DECRAENE \& SMETS 1993a: 
Figs 26, 27). Outer staminodes occur also in the Myrtaceae (Chamaelaucium uncinatum: Fig. 10; RONSE DECRAENE \& SMETS 1991 c).

In other cases antepetalous stamens are only apparently paired. This is the case for certain Rhizophoraceae, such as Rhizophora and Bruguiera because of a displacement of the antesepalous stamens in a pouch formed by the petals. Stamens of different whorls are also of unequal length (BAILLON 1875a, b; JUNCOSA 1988). In Tetratheca (Tremandraceae) paired stamens are apparently inserted opposite the petals, but their vasculature is derived from a sepal-positioned supply (SAUNDERS 1939).

\section{Phylogenetic shift of stamens}

Multistaminate androecia consisting of numerous alternating whorls (polycycly) often have numerous stamens in paired and unpaired positions (see Ronse DECRAENE \& SMETS 1990a, 1991 a, 1993b, 1995a). Indeed, trimerous polycyclic flowers have a variable number of alternating whorls of three and six (viz. paired) stamens. The outer stamens are inserted as three pairs and the upper part of the androecium shows an alternation of hexamerous and trimerous whorls (Figs. 14-16). In dimerous flowers one finds exactly the same situation, but with an alternation of whorls of two and four (viz. paired) stamens (Figs. 17-19, see Ronse DeCRAENE \& SMETS 1994). We believe that the presence of paired stamens in upper whorls of polycyclic androecia is not incidental and is not the result of doubling (contrary to ENDRESS 1987, 1994), but follows a strictly settled ontogenetic sequence. For example, the occurrence of upper hexamerous whorls of stamens in the Papaveraceae (e.g. ENDRESS 1987; RONSE DECRAENE \& SMETS 1990b; KARRER 1991) cannot be the result of doubling of stamens with shifts in merosity (sensu ENDRESS 1987 ) as the hexamerous whorl may arise in two times and at a different level (Fig. 17:4 and 5). These facts tend to substantiate the hypothesis of ERBAR \& LEINS $(1981,1983,1994)$ who derived trimerous non-spiral androecia with paired outer stamens from a basic spiral initiation by a break in the ontogenetic spiral. However, this pattern of inception should not be restricted to trimerous flowers only, because dimerous (and by derivation pentamerous flowers) may arise in the same sequence and with the same alternation of whorls of paired and single stamens (cf. RONSE DECRAENE \& SMETS 1994).

ENDRESS $(1987,1994)$ proposed dédoublement as the only explanation for paired structures. He illustrated this with examples of organs occasionally arranged in doubled position. The outer stamen pairs are interpreted as "a doubling of organ position", "at the transition from the corolla to the androecium" (ENDRESS 1994: 98). Stamens may also halve in higher whorls and this is related to the rate of further expansion of the floral apex.

However, his interpretation presents a number of inconsistencies:

(a) It does not reflect possible differences in the origin of the perianth. For example, "petals" are not necessarily homologous structures. They are undoubtedly of a tepaline nature in those trimerous/dimerous flowers with paired outer stamens (e.g. Annonaceae, Papaveraceae, some Ranunculaceae), but not necessarily in pentamerous flowers where "staminopetals" are the rule. It is thus not possible to compare these two conditions.

(b) The strictly sequential initiation of stamens in clearly alternating whorls (e.g. Figs. 16, 17) makes doublings in different whorls highly improbable (see before). Moreover, the floral apex does not seem to expand to such extent as to be a necessity in providing space for an increase of stamens.

(c) There is absolutely no evidence for a generalized increase (dédoublement) in the groups ENDRESS considers. Examples of a true doubling given by ENDRESS (1994: Figs. 2.39, $1-3$ ) occur only occasionally (as our Figs. 3-5).

That the presence of outer stamen pairs linked with a common mode of inception is basic and widespread can be illustrated with a few examples. We found a remarkable similarity in the floral diagrams and floral initiation patterns of the stamens in dimerous taxa with outer stamens pairs, such as the Nepenthaceae (STERN 1917), Polygonaceae (Ronse DECRAENE \& AKEROYD 1988); Begoniaceae (Ronse DECRAENE \& SMETS 1990 b), Phytolaccaceae (subfamily Rivinoideae, with a reversed inception: Fig. 22; RONSE DECRAENE \& SMETS 1991 b). Papaveraceae (Fig. 17; ENDRESS 1987; KARRER 1991; MURBECK 1912; Ronse DeCraene \& SMets 1990b), Buxaceae (VAN TIEGHEM 1897), dimerous Ranunculaceae (Figs 18, 19, SCHÖFFEL 1932; LEHMANN \& 


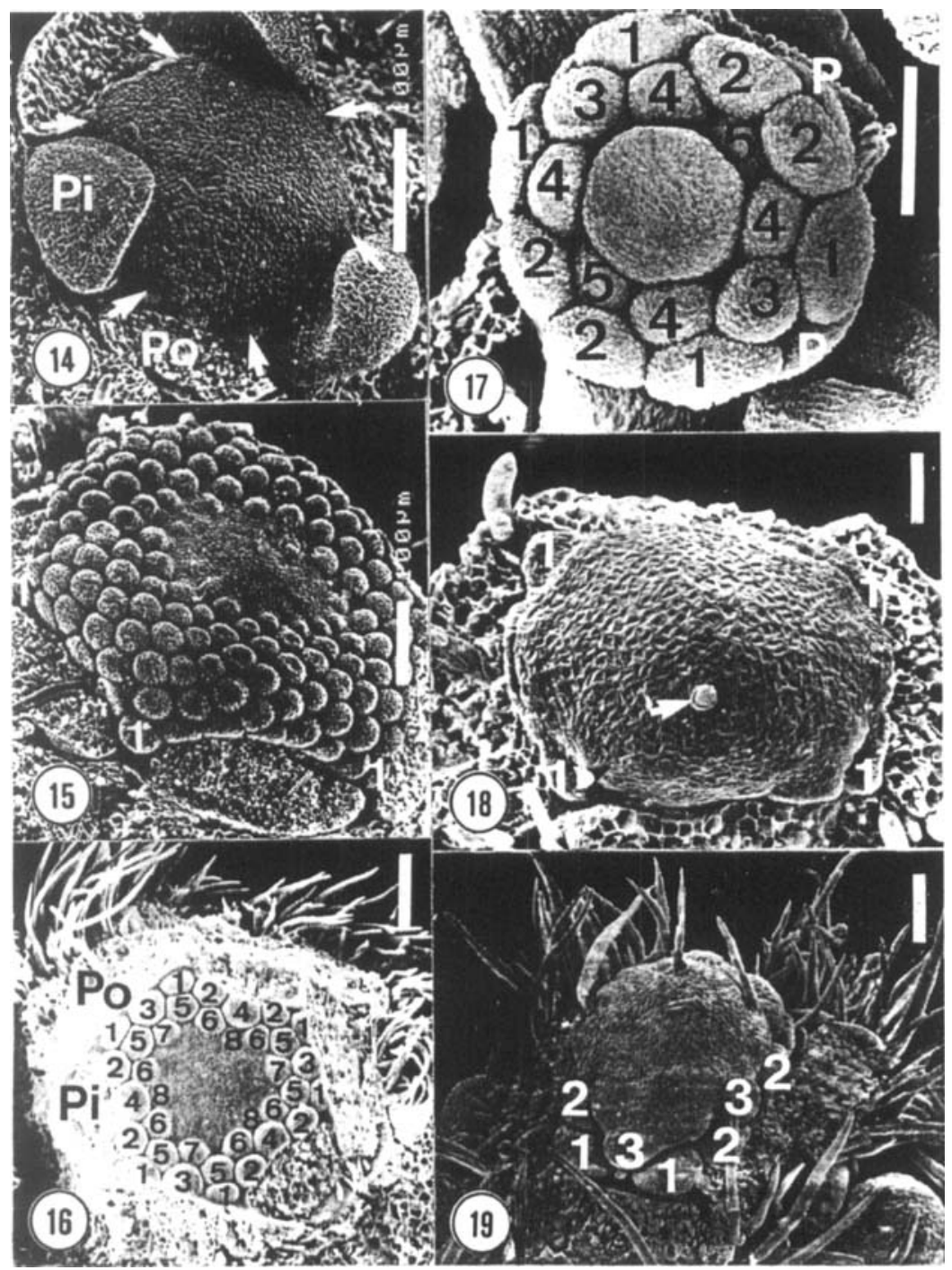

Figs. 14-19

Examples of phylogenetic shifts of stamens with a paired arrangement

Figs 14, 15 - Polyalthia suberosa BENTH. \& HOOK. (Annonaceae)

14 - Young bud showing outer stamens (arrows) forming pairs and some stamens of a higher whorl. 15 - Stage at the inception of the carpeis. Note the outer stamen pairs and more or less regular arrangement of numerous stamens in the whorl

Fig. 16 - Monanthotaxis whytei (STAPF) VERDC. (Annonaceae)

Early stage of stamen and carpel inception, numbering gives the regular order of the inception

Fig. 17 - Eschscholzia caespitosa BENTH. (Papaveraceae)

Dimerous flower with an alternation of dimerous and tetramerous whorls making up "pseudowhorls" of six stamens ( 2 with 3 , and 4 with 5)

Figs. 18, 19 - Clematis recta L. (Ranunculaceae)

18 - Apical view of first stamen initiation in the comers alternating with the sepals; arrow points to a trichome arising on the floral meristem. 19 -Older but with inception of three whorls of stamens (numbers); note the older trichomes Abbreviations: $\mathrm{P}$ - petal; $\mathrm{Pi}$ - inner petal; $\mathrm{Po}$ - outer petal. Scale bars $=100 \mu \mathrm{m}$, except Fig. $18=50 \mu \mathrm{m}$ 
Sattler 1994), Fumariaceae (Ronse Decraene \& SMETS 1992), Capparaceae (Fig. 25, EICHLER 1865; PAX 1888; KARRER 1991; ENDRESS 1992) and Brassicaceae (EICHLER 1865; ENDRESSS 1992; Ronse DeCraene \& SMETS 1993 a, b). Following the successive initiation of two perianth whorls, four stamen primordia (or petal primordia in Capparaceae and Brassicaceae) are always initiated in alternation with the perianth parts or in pairs opposite the outer perianth segments. Next, a whorl of six stamen primordia is usually incepted in two times, sometimes only four (also in two times, as e.g. in Ledenbergia or in Trichostigma: Fig. 22; Ronse DeCraene \& Smets 1991 b) or only two (Fumariaceae. Fig. 23; Notobuxus of the Buxaceae). In the Fumariaceae only two inner stamens are initiated and make up a pseudowhorl with the four previously initiated stamens (Figs. 23, 24). In the Capparaceae (Cleomoideae) and Brassicaceae the six stamens may arise simultaneously or in two times and possibly at different insertion levels (e.g. Fig. 25, KaRRER 1991 , pers. obs.). This common mode of initiation (viz. four outer alternitepalous stamen primordia) is characteristically distributed among dimerous taxa and does not differ from trimerous groups with a similar mode of inception, except for the loss of a sector in the flower. We believe this to be of great taxonomic significance (see also RONSE DECRAENE \& SMETS 1993b, 1994).

Reductions of the upper whorls occur frequently in representatives with trimerous or dimerous flowers. This usually leads to fewer stamens, but the outermost stamen pairs remain usually present (see RONSE DECRAENE \& SMETS 1993b). This can be illustrated for Laurus nobilis (Lauraceae) with dimerous flowers (Figs. 20,21). The outer stamens alternate with the tepals (two pairs); there is an intermediate whorl of two stamens (sometimes four in two whorls: Fig. 21) forming a pseudowhorl with a third whorl of two, and also a fourth whorl. In older buds stamens are displaced by pressure of the tightly packed inflorescence (not illustrated).

Very often the paired stamens of upper whorls and sometimes also the outer pairs become replaced by single entities (Fig. 24); this shift may be linked with a reduction of space for the inception of primordia (cf. SATTLER \& SiNGH 1978; RONSE DECRAENE \& SMETS 1993b, 1995a). In an ultimate stage the pairs become replaced by single stamens or the pairs remain present but become replaced by petals through a process of homeosis (Fig. 25).

\section{Distribution and conclusion}

We thus believe that there are two strictly different evolutionary patterns leading to stamen pairs: (1) pairs formed by a secondary increase and (2) pairs formed by a phylogenetic shift. The distribution of paired stamens has been plotted on a classification diagram of DAHLGREN (1989) (Fig. 26). The black dots refer to the presence of outer stamen pairs, linked with shifts in stamen position (what can be inferred by the presence of few or numerous stamen whorls, an often undifferentiated perianth and mainly trimerous or dimerous flowers). This state is found basically in the Liliatae, Magnoliidae, Caryophyllidae and part of the Hamamelidae of CRONQUIST (1981), where we could find no evidence for an origin of the pairs by doubling. It is also found scattered in a few dimerous families placed in the Dilleniidae by Cronquist (1981), such as Nepenthaceae, Brassicaceae, Capparaceae, Begoniaceae, Batidaceae and Begoniaceae. The position of these families outside a "polymerous alliance" has been questioned by us (RONSE DECRAENE \& SMETS 1993b). No evidence exists that the outer stamen pairs of trimerous or dimerous flowers arose by the division of complex primordia. The situation in Saururaceae with common primordia, such as Anemopsis and Gymnotheca (TUCKER 1985; LIANG H.-X. \& TUCKER 1989) should be seen as a shift to single stamens (as in Houttuynia: TUCKER 1981) and is linked with the zygomorphy of the flowers (see also TUCKER et al. 1993). A similar shift to single stamens can be observed in Hypecoum (Fig. 24; RONSE DECRAENE \& SMETS 1992).

Stamen pairs related to dédoublement occur either in antesepalous position, or in antepetalous position and are mainly scattered among taxa of the Dilleniidae and Rosidae. In the other subclasses, doubling occurs only exceptionally (Fig. 5 , JoSHI 1932), while stamen pairs are correlated with a strict mode of inception of the androecium.

We have not encountered situations with paired stamens both in antesepalous and antepetalous position, except in Lythraceae and Anacardiaceae (Table). The reason for this is perhaps a lack of space or the absence of harmony in triggering an increase in both whorls. Paired antesepalous sta- 


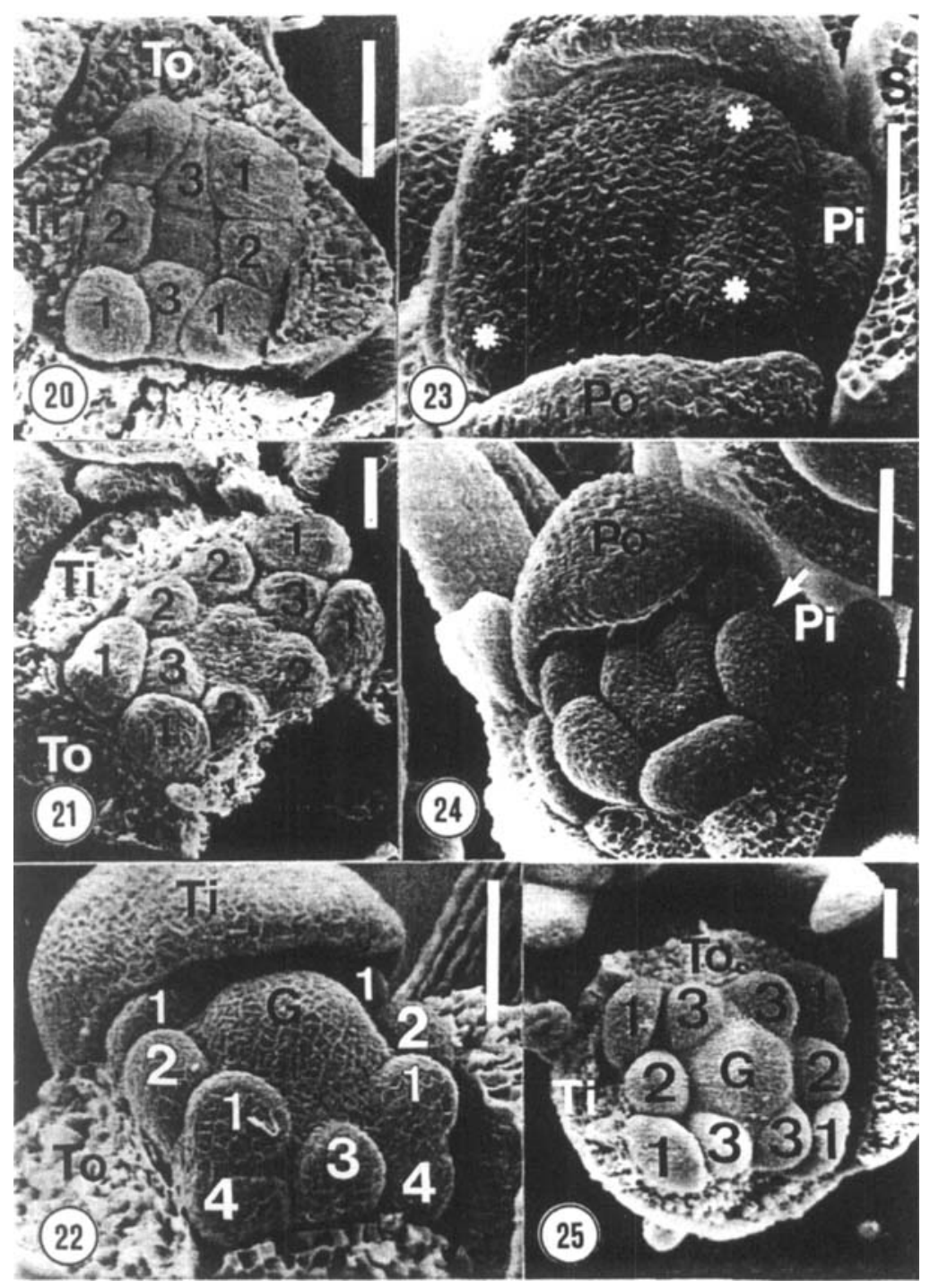

Figs. 20-25

Illustrations of reductive trends of polycyclic androecia

Figs. 20, 21 - Laurus nobilis L. (Lauraceae), tepals removed

20 - Flower bud with three whorls forming two pseudowhorls of four stamens, 21 - Exceptional bud with the second whorl arising as a pair

Fig. 22 - Trichostigma peruvianum (MoQ.) H. WALT. (Phytolaccaceae)

Young flower bud with centrifugal initiation of stamens in dimerous and tetramerous whorls (numbers)

Figs. 23, 24-Hypecoum procumbens L. (Fumariaceae)

23 - Appearance of first four stames as two pairs (asterisks); 24 - Older bud showing the median concrescence of the first formed stamens (arrow) and the initiation of a lateral stamen

Fig. 25 - Cleome spinosa L. (Capparaceae)

Flower bud showing inception of three stamen whorls, the outer being replaced by petals

Abbreviations: $\mathrm{G}$ - gynoecium; $\mathrm{Pi}$ - inner petal, $\mathrm{Po}$ - outer petal; $\mathrm{Ti}$ - inner tepal; To - outer tepal. Scale bars $=100 \mu \mathrm{m}$, except Figs. $21,22,23,25=50 \mu \mathrm{m}$ 
L. P. RONSE DECRAENE et al., Morphol. variation and system. value of stamen pairs in Magnoliatae

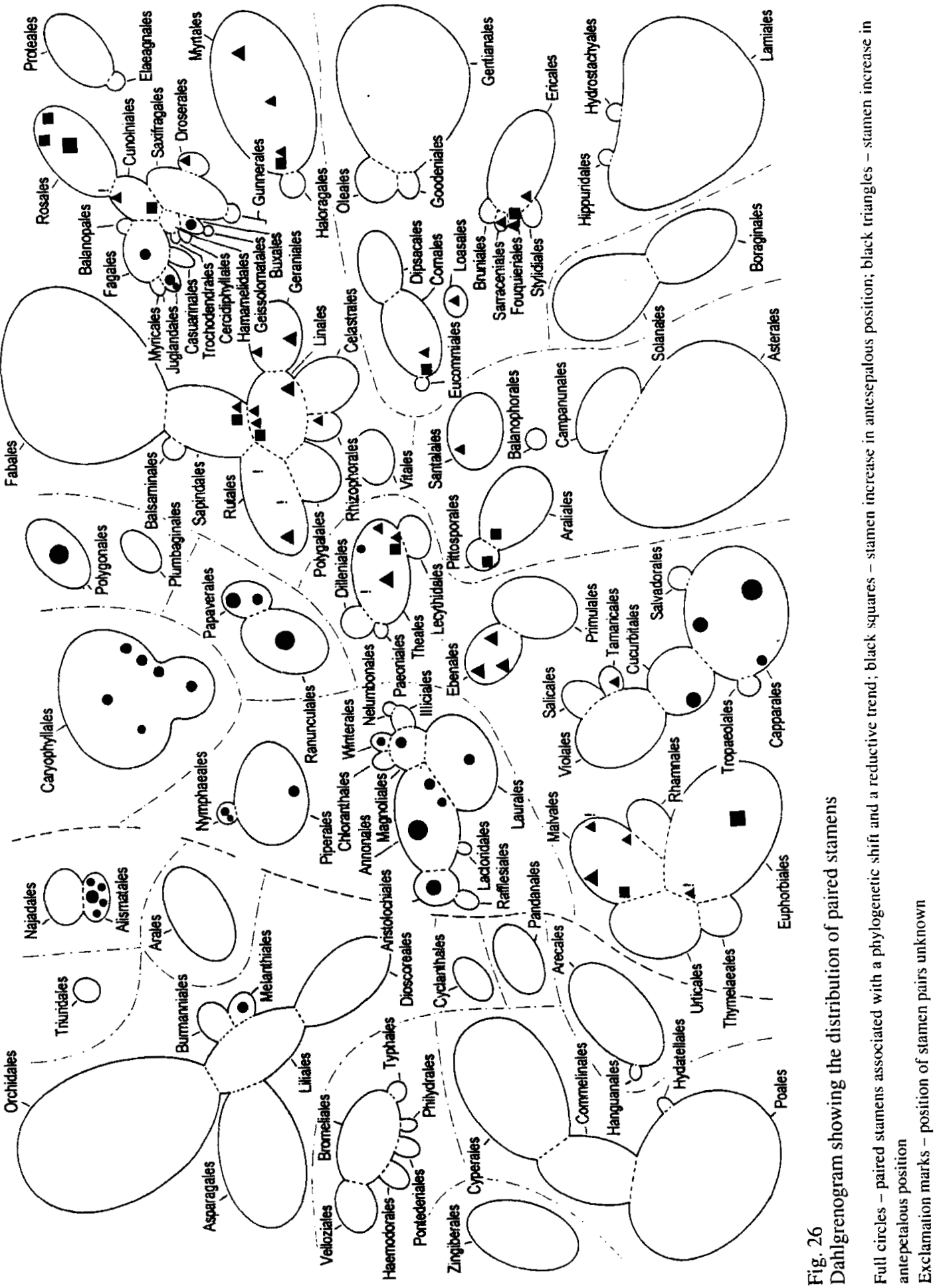


Table

The distribution of androecia with stamens in pairs or in triplets in the Magnoliatae, linked with dédoublement (families given in alphabetical order)

(1) number of stamens in antesepalous position

(2) number of stamens in antepetalous position

(3) presence of obdiplostemony

(4) authority

(5) affected genera

Occasional increases by dédoublement are not considered (e.g. Figs. 3-5);

- refers to the presence of sterile stamens; ${ }^{2}$ alternisepalous groups of two stamens.

families indicated with * have representatives with fifteen stamens;

the numbers under (1) and (2) are to be taken together in sequence as more possibilities exist. For example, Chrysobalanaceae have a single stamen in antesepalous position and an antepetalous pair, or a pair in antesepalous position and single antepetalous stamens.

\begin{tabular}{|c|c|c|c|c|c|}
\hline family & (1) & (2) & (3) & (4) & $(5)$ \\
\hline Actinidiaceae* & 1 & 2 & - & CORNER 1946 & Saurauia \\
\hline Aizoaceae & 0 & $2^{a}$ & - & HOFMANN 1993 & Galenia \\
\hline Anacardiaceae & 2 & 2 & + & EICHLER 1878 & Sclerocarya \\
\hline Aquifoliaceae & 2 & 0 & - & BAILEY \& SWAMY 1953 & Sphenostemon \\
\hline Araliaceae & 2 & 0 & - & BAILLON 1876; SAUNDERS 1939 & Dizygotheca. Plerandra \\
\hline Bombacaceae* & 0 & $2-3$ & - & $\begin{array}{l}\text { MOQUIN-TANDON } 1826 \\
\text { BAILLON } 1871 ; \text { HEEL } 1966\end{array}$ & Marwellia, Quararibia \\
\hline Brunelliaceae* & 1 & 2 & - & CRONQUIST 1981 & Brunellia \\
\hline Caesalpiniaceae* & $i$ & $2^{\circ}$ & - & BAILLON 1865; ENDRESS 1994 & Pentaclethra, Batuhinia \\
\hline Chrysobalanaceae* & $1-2$ & $2-1$ & - & EICHLER I878; MURBECK 1941 & Licania, Chnsobalanus \\
\hline Cistaceae* & 1 & 2 & $?$ & JANCHEN 1925 & Lechea \\
\hline Clusiaceae* & $1 ?-0$ & $2 ?-3$ & - & ARBER 1913; ENGLER 1925 & Hypericum, Clusia \\
\hline Combretaceae* & 1 & 2 & - & EICHLER 1866; CRONQUIST 1981 & Combretum, Cacoucia \\
\hline Crossosomataceae* & ? & ? & ? & THORNE 1977; GOLDBERG 1986 & Apacheria \\
\hline Ctenolophonaceae* & 1 & 2 & + & CRONQUIST 1981 & Ctenolophon \\
\hline Cunoniaceae* & 2 & 1 & - & ENGLER 1930; DICKISON 1975 & Callicoma \\
\hline Dipterocarpaceae* & 2 & 1 & - & EICHLER 1878; RAO 1962 & Hopea, Vatica \\
\hline Droseraceae* & 1 & 2 & - & PAYER 1857; SMITH 1929 & Dionaea \\
\hline Ebenaceae* & 1 & 2 & - & EICHLER 1878; SAUNDERS 1939 & Diospyros, Euclea \\
\hline Elaeocarpaceae* & 1 & 2 & + & HEEL 1966; BALGOOY 1976 & $\begin{array}{l}\text { Aceratium, Aristotelia, } \\
\text { Tricuspidaria }\end{array}$ \\
\hline Euphorbiaceae* & 2 & 1 & - & $\begin{array}{l}\text { BEILLE } 1901 \text {; VENKATA RAO \& } \\
\text { RAMALAKSHMI } 1968\end{array}$ & $\begin{array}{l}\text { Chrozophora, Manihot, } \\
\text { Croton }\end{array}$ \\
\hline Flacourtiaceae* & 0 & 3 & - & $\begin{array}{l}\text { MOQUIN-TANDON 1826: } \\
\text { PAUWELS I } 993\end{array}$ & Homalium \\
\hline Fouquieriaceae* & $1-2$ & $2-1$ & - & $\begin{array}{l}\text { SAUNDERS } 1939 \\
\text { HENRICKSON } 1971\end{array}$ & Fouquieria \\
\hline Geraniaceae* & 1 & 2 & + & $\begin{array}{l}\text { KNUTH } 1931 \text {; SAUNDERS 1939; } \\
\text { NARAYANA \& ARORA 1963; } \\
\text { KUMAR } 1976\end{array}$ & Sarcocaulon, Monsonia \\
\hline Humiriaceae* & 3 & 1 & - & $\begin{array}{l}\text { NARAYANA \& RAO 1973a, b, } \\
1976\end{array}$ & $\begin{array}{l}\text { Schistostemon, Humiria, } \\
\text { Humiriastrum }\end{array}$ \\
\hline Hydrangeaceae* & 3 & $0-1$ & - & $\begin{array}{l}\text { RONSE DECRAENE \& SMETS } \\
\text { 1995b; KAPPELER } 1995\end{array}$ & $\begin{array}{l}\text { Hydrangea, } \\
\text { Kirengeshoma }\end{array}$ \\
\hline Ixonanthaceae* & 1 & 2 & + & NARAYANA \& RAO 1966 & Ixonanthes \\
\hline Loasaceae* & 1 & 2 & + & URBAN 1892 & Mentzelia \\
\hline Lythraceae* & 2 & $0-2$ & - & EICHLER 1878; SAUNDERS 1939 & Lawsonia, Physocalymmo \\
\hline Meliaceae* & ? & $?$ & $?$ & EICHLER 1878 & Vavaea \\
\hline Myrtaceae & 1 & 3 & + & $\begin{array}{l}\text { BAILLON 1873; RONSE DECRAENE } \\
\& \text { SMETS } 1991 \mathrm{c}\end{array}$ & $\begin{array}{l}\text { Darwinia, } \\
\text { Chamaelaucium }\end{array}$ \\
\hline
\end{tabular}


Table (continued)

\begin{tabular}{|c|c|c|c|c|c|}
\hline family & ( 1 ) & (2) & (3) & (4) & (5) \\
\hline Olacaceae* & $0-1$ & $3(2)-2(3)$ & - & $\begin{array}{l}\text { BAILLON } 1862 ; \text { SLEUMER } 1935 ; \\
\text { REED } 1955\end{array}$ & Ochanostachys, Coula \\
\hline Oxalidaceae* & 1 & 2 & + & $\begin{array}{l}\text { KNUTH } 1931 \text {; SAUNDERS } 1939 ; \\
\text { RaMa DEVI 1991 }\end{array}$ & Hypseocharis \\
\hline Pandaceae* & $1 ?$ & $2 ?$ & ? & CRONQUIST 1981 & Galearia, Microdesmis \\
\hline Quiinaceae* & $?$ & $?$ & $?$ & ENGLER 1925 & Quiina \\
\hline Rosaceae* & 2 & $1(0)$ & - & $\begin{array}{l}\text { Kania 1973; Evans \& Dickinson } \\
1994\end{array}$ & Crataegus, Cotoneaster \\
\hline Rutaceae* & 1 & 2 & + & $\begin{array}{l}\text { ENGLER } 1931 ; \text { TILLSON \& } \\
\text { BAMFORD } 1938\end{array}$ & Afraegle, Pleurandropsis \\
\hline Sapotaceae* & $1^{\circ}$ & 2 & - & SAUNDERS 1939 & Bassia \\
\hline Sarraceniaceae ${ }^{*}$ & 0 & $3-2+$ & - & UPHOF 1936 & Darlingtonia, Sarracenia \\
\hline Simaroubaceae* & $?$ & $?$ & - & ENGLER 1931 & Mannia \\
\hline Sterculiaceae* & $1^{\circ}-0$ & $2-3$ & + & $\begin{array}{l}\text { VENKATA RAO 1952; HEEL 1966; } \\
\text { JENNY } 1989\end{array}$ & $\begin{array}{l}\text { Theobroma, Firmiana, } \\
\text { Sterculia }\end{array}$ \\
\hline Styracaceae* & 1 & 2 & - & $\begin{array}{l}\text { PAYER 1857; SAUNDERS 1939; } \\
\text { DICKISON } 1993\end{array}$ & Pterostyrax \\
\hline Tamaricaceae* & 1 & 2 & - & ZOHARY \& BAUM 1965 & Tamarix \\
\hline Theaceae* & $1-3 ?$ & $2-0 ?$ & + & PAYER 1857; CORNER 1946 & Visnea \\
\hline Tremandraceae & & 0 & - & PAYER 1857; SAUNDERS 1939 & Tetratheca \\
\hline Zygophyllaceae* & $1-3$ & $2-0$ & + & $\begin{array}{l}\text { KUMAR 1976; RONSE DECRAENE } \\
\text { \& SMETS } 199 \text { l a; RONSE DECRAENE } \\
\text { et al. } 1996\end{array}$ & Peganum, Nitraria \\
\hline
\end{tabular}

mens (black squares on Fig. 26) tend to be scattered over different superorders with little taxonomic significance. Paired antepetalous stamens (black triangles on Fig. 26) on the contrary have a much wider distribution and are characteristic for certain orders, such as Malvales, Ebenales, Geraniales and Linales.

Paired stamens are often related to obdiplostemony (Table). It is hypothesized that the doubling of the antepetalous stamen whorl results in their retardation in initiation (arising centrifugally and more externally) and a reduced size of the primordia (Figs. 8, 9; RoNSE DECRAENE et al. 1996; RONSE DECRAENE \& SMETS 1995b).

The distribution of paired stamens on the Dahlgrenogram (Fig. 26) corresponds more or less with a proposed distinction between a polymerous and an oligomerous alliance (see RONSE DECRAENE \& SMETS 1987, 1993b, 1995b). In polymerous taxa stamen pairs are correlated with a reductive trend, where pairs may be replaced by single stamens or petals; in oligomerous taxa stamen pairs reflect an increase in the pollination potential, that has arisen several times inde- pendently. Indeed, doubling can suddenly increase the number of stamens in the flower, offering greater rewards to visiting insects and new possibilities for floral evolution.

The proposed distinction corresponds to earlier divisions in two major groups proposed by KubitzKI (1969, 1973), KUBITZKI \& GotTliEB (1984a, b) and HUBER (1982) and is supported by phytochemical (KUBITZKI \& GotTLIEB 1984a, b), as well as evidence of epicuticular waxes (BARTHLOTT 1990). It is also roughly reflected in the $r b c \mathrm{~L}$ tree of CHASE et al. (1993) who obtained a split between two major groups with different pollen types (monosulcate and monosulcate-derived versus tricolpate and tricolpate-derived), except for taxa such as the lower eudicots and Caryophyllids.

\section{Acknowledgements}

Part of this paper was presented by the first author at the 12th Symposium Morphologie, Anatomie und Systematik held at Mainz in March 1995. We thank Prof. Dr. J. Rammeloo for permission to collect material and use the SEM facilities of the National 
Botanic Gardens of Belgium in Meise. M. Verhae ge $n$ is acknowledged for technical assistance. We appreciate Mrs Beate Oosterly nck's help in correcting the german summary and Mrs Catherine Ronse Decraene for drawing the floral diagrams. This study was supported by research grants (project $n^{\circ} 2.0038 .91: S E M$ and project $n^{\circ}$ G.0143.95: general research project) from the National Foundation of Scientific Research (N.F.W.O). The leading author is a postdoctoral researcher of the N.F.W.O.

\section{References}

ARBER, A., 1913, On the structure of the androecium in Parnassia and its bearing on the affinities of the genus. Ann. Bot., 27, 491-510.

Balley, I. W.: Swamy, B. G. L., 1953. The morphology and relationships of Idenburgia and Nouhuy. sia. J. Arnold Arbor., 34, 77-85.

BAILLON, H., 1862, Deuxième mémoire sur les Loranthacées. Adansonia, 3, 50-128.

Baillon, H., 1865, Etudes sur l'herbier du Gabon. Adansonia, 6. 177-230.

Baillon, H., 1871, Sur le nouveau genre Marwellia. Adansonia, 10, 98-100.

BaILlON, H., 1873, Traité du développement de la fleur et du fruit. IX. Chamaelauciées. Adansonia, 11, $361-365$.

Baillon, H., 1875a, Sur l'androcée des Rhizophoracées. Bull. Mens. Soc. Linn. Paris, 1 (8), 58-59.

Baillon, H., 1875b, Sur les fleurs et les fruits de Napoleona. Bull. Mens. Soc. Linn. Paris, 1 (8), 59-62.

BAILLON, H., 1876, Recherches nouvelles sur les Araliées et sur la famille des ombellifères en général. Adansonia, 12, 125-178.

Baillon, H., 1885, La symétrie florale et l'androcée des Telfairia. Bull. Mens. Soc. Linn. Paris, 1 (60), 473.

BAllLON, H., 1892, Histoire des plantes 11 . Ebénacées. pp. 221-229. Paris.

Balgooy, M. M. J. van, 1976, A note on Aceratium ferrugineum C.T. White (Elaeocarpaceae). Blumea, 23, 49-50.

BARTHLOTT, W., 1990, Scanning electron microscopy of the epidermal surface in plants. In: Scanning electron microscopy in taxonomy and functional morphology ed. by D. Claugher. Systematics Association, Special Volume, 41, 69-83. Oxford.

BeILle, M. L., 1901, Recherches sur le développement floral des Disciflores. Actes Soc. Linn. Bordeaux, 56, 235-410.

Bensel, C. R.; PALSER, B. F., 1975, Floral anatomy in the Saxifragaceae sensu lato III. Kirengeshomoideae, Hydrangeoideae and Escallonioideae. Amer. J. Bot., 62, 676-687.
Chase, M. W.; Soltis, D. E.; Olmstead, R. G., MorGan, D.; Les, D. H.; Mishler, B. D.; Duvall, M. R.; Price, R. A.; HILls, H. G.; GIU, YIN-LONG, Kron. K. A.; Rettig. J. H.; Conti. E.; Palmer, J. D.; Manhart, J. R.; Sytsma, K. J.; Michaels, H. J.; KRESS, W. J.; KaROL, K. G. ; ClaRK, W. D.; Hedrén. M.: GaUt, B. S.; Jansen, R. K.; KIM, KI-JOONG; WIMPEE, C. F.; SMITH, J. F.; FURNIER, G. R.; Strauss, S. H., YIANG, QIU-Yun; PlunKETT, G. M.; SOlTIS, P. S.; SWENSEN, S. M.; WILliams, S. E.; Gadek, P. A.; Quin, C. J., Eguiarte, L. E.; GoldenberG, E.; Learn, G. H. Jr.; Graham, S. W.; Barrett, S. C. H.; Selvadural Dayanandan, Albert, V. A., 1993, Phylogenetics of seed plants: an analysis of nucleotide sequence from the plastid gene rbsL. Ann. Missouri Bot. Gard., 80, 528-580.

Corner, E. J. H., 1946, Centrifugal stamens. J. Arnold Arbor., 27, 423-437.

CRONQuist, A., 1981, An integrated system of classification of flowering plants. New York.

Dahlgren, G., 1989; An updated angiosperm classification. Bot. J. Linn. Soc., 100, 197-203.

Dickison, W. C., 1975, Studies on the floral anatomy of the Cunoniaceae. Amer. J. Bot., 62, 433-447.

DiCkison, W. C., 1993, Floral anatomy of the Styracaceae, including observations on intra-ovarian trichomes. Bot. J. Linn. Soc., 112, 223-255.

Dutailly, G., 1876. Sur la fleur mâle des Corvlus. Bull. Soc. Linn. Paris, 1 (20), 157-160.

EICHLER, A. W., 1865, Ueber den Blüthenbau der Fumariaceen, Cruciferen und einiger Capparideen. Flora, 48, 433-444, 449-460, 497-508, 513-521, 529-536, 545-558.

EICHLER, A. W., 1866, Thiloa and Buchenavia, zwei neue Gattungen der Combretaceen. Flora, 49. $145-152 ; 161-167$.

EICHLER, A. W., 1878; Blüthendiagramme 2. Leipzig.

ENDRESS, P. K., 1987, Floral phyllotaxis and floral evolution. Bot. Jahrb. Syst., 108, 417-438.

ENDRESS, P. K., 1992, Evolution and floral diversity: the phylogenetic surroundings of Arabidopsis and Antirrhinum. Int. J, Plant Sci., 153, S106-S122.

ENDRESS, P. K., 1994, Diversity and evolutionary biology of tropical flowers. Cambridge.

ENDRESS, P. K. ; STUMPF, S., 1990, Non-tetrasporangiate stamens in the angiosperms : structure, systematic distribution and evolutionary aspects. Bot. Jahrb. Syst., 112, 193-240.

ENGLeR, A., 1925, Quiinaceae, Guttiferae. In: Die natürlichen Pflanzenfamilien, 2nd ed./ed. by A. Engler and K. Prantl. Vol. 21, 106-108; 154-237. Leipzig.

ENGLER, A., 1930, Cunoniaceae. In: Die natürlichen Pflanzenfamilien, 2nd ed./ed. by A. ENGLER and K. PrantL. Vol. 18a, 229-262. Leipzig.

ENGLER, A., 1931, Rutaceae, Simaroubaceae. In: Die natürlichen Pflanzenfamilien, 2nd ed./ed. by 
A. EnGler and K. Prantl. Vol. 19a, 187-359; 359-405. Leipzig.

ERBar, C., 1994, Contributions to the affinities of Adoxa from the viewpoint of floral development. Bot. Jahrb. Syst., 116, 259-282.

ERBAR, C.; LeINS, P., 1981, Zur Spirale in MagnolienBlüten. Beitr. Biol. Pflanzen, 56, 225-241.

Erbar, C.; Leins, P., 1983, Zur Sequenz von Blütenorganen bei einigen Magnoliiden. Bot. Jahrb. Syst., 103, 433-449.

Erbar, C.; Leins, P., 1994, Flowers in Magnoliidae and the origin of flowers in other subclasses of the angiosperms 1 . The relationships between flowers of Magnoliidae and Alismatidae. Pl. Syst. Evol. (Suppl.), 8, 193-208.

Evans, R. C.; Dickinson, T. A., 1994, Floral development of 10- and 20-stamen varieties of Crataegus douglasii Lindley (Rosaceae: Maloideae). Amer. J. Bot. (suppl. abstracts), 80 (6), 23.

GoldberG, A., 1986, Classification, evolution and phylogeny of the families of Dicotyledons. Smithson. Contr. Bot., 58, 1-314.

HeEL, W. A. VAN, 1966, Morphology of the androecium in Malvales. Blumea, 13, 177-394.

HenRickson, J., 1972, A taxonomic revision of the Fouquieriaceae. Aliso, 7, 439-537.

HofmanN, U., 1993, Flower morphology and ontogeny. In: Caryophyllales. Evolution and Systematics ed. by H.-D. BEHNKE and T. J. MABRY, 123-. 166. Berlin.

Huber, H., 1982, Die zweikeimblättrigen Gehölze im System der Angiospermen. Mitt. Bot. Staatssamml. München, 18, 59-78.

JANCHEN, E., 1925, Cistaceae. In: Die natürlichen Pflanzenfamilien, 2nd ed./ed. by A. ENGLER and K. PrantL. Vol. 21, 289-313. Leipzig.

JeNNY, M., 1989, Organstellung und Androeciumentwicklung ausgewähiter Sterculiaceae. 9. Symposium Morphologie, Anatomie und Systematik, Wien, Zusammenfassung der Vorträge, 26.

JosHI, A. C., 1932, Dédoublement of stamens in Achyranthes aspera Linn. J. Indian Bot. Soc., 11, 335339.

JunCOSA, A. M., 1988, Floral development and character evolution in Rhizophoraceae. In: Aspects of floral development/ed. by P. LEINS, S. C. TUCKER and P. K. ENDRESS, 83-101. Berlin.

KANIA, W., 1973, Entwicklungsgeschichtliche Untersuchungen and Rosaceenblüten. Bot. Jahrb. Syst., 93, $175-246$.

KaPPELER, G., 1995, Anlage des Androeciums bei einigen Vertretern der Hydrangeaceae. 12. Symposium Morphologie, Anatomie und Systematik, Mainz, Zusammenfassung der Vorträge.

KARRER, A. B., 1991, Blütenentwicklung und systematische Stellung der Papaveraceae und Capparaceae. Unpubl. doct. thesis, Univ. Zürich.
KNUTH, R., 1931, Oxalidaceae. Geraniaceae. In: Die natïrlichen Pflanzenfamilien, 2nd ed./ed. by $A$. Engler and K. PrantL. Vol. 19a, 11-66. Leipzig.

KUBITZKI, K., 1969, Chemosystematische Betrachtungen zur Großgliederung der Dicotylen. Taxon, 18, $360-368$.

Kubitzki, K., 1973, Probleme der Großsystematik der Blütenpflanzen. Ber. Deutsch. Bot. Ges., 85, 259277.

Kubitzki, K.; GotTlieb, O. R., 1984 a, Micromolecular patterns and the evolution and major classification of angiosperms. Taxon, 33, 375-391.

Kubitzk1, K,; GotTlieb, O. R., 1984b, Phytochemical aspects of angiosperm origin and evolution. Acta Bot. Neerl.. 33, 457-468.

Kumar, A., 1976. Studies in Geraniales II. The floral anatomy. J. Indian Bot. Soc., 55, 233-253.

LehMANN, N.: SATtLER, R., 1994, Floral development and homeosis in Actaea rubra (Ranunculaceae). Int. J. Plant. Sci., 155, 658-671.

LEINS, P.: ERBAR. C., 1985, Ein Beitrag zur Blütenentwicklung der Aristolochiaceen, einer Vermittlergruppe zu den Monokotylen. Bot. Jahrb. Syst., 107, 343-368.

Liang, HAN-XING: TUCKER, S. C., 1989, Floral development in Gymnotheca chinensis. Amer. J. Bot., 76. 806-819.

LINDENHOFER. A.; WEBER, A., 1995, Das Androeceum der Rosaceae - sekundäre oder primäre Poly. andrie? 12. Symposium Morphologie, Anatomie und Systematik, Mainz, Zusammenfassung der Vorträge.

Moquin-Tandon, A., 1826, Essai sur les dédoublemens [sic] ou multiplications d'organes dans les végétaux. Montpellier.

MURBECK, S., 1912, Untersuchungen über den Blütenbau der Papaveraceen. Kongl. Svenska Vetensk. Akad. Handl., 50, 1-168.

MURBECK, S.. 1941, Untersuchungen über das Androecium der Rosaceen. Lunds. Univ. Årsskr., 37. $1-56$.

NaiR, N. C.; Abraham, V., 1962, Floral morphology of a few species of Euphorbiaceae. Proc. Indian Acad. Sci.. B56, $1-12$.

Narayana, H. S.; ARORA, P. K., 1963, Floral anatomy of Monsonia senegalensis Guill. \& Perr. Curr. Sci., 32, 184- 185 .

NARAYANA, LL.: RAO, D., 1966, Floral morphology of Linaceae. J. Jap. Bot., 41, 1-10.

Narayana, Ll.: RaO, D., 1973a, 1973b, 1976, Contributions to the floral anatomy of the Humiriaceae 2, 3, 5. J. Jap. Bot., 48, 143-146; 242-246; 51, $42-44$.

Pauwels, L., 1993, Nzayilu N'ti. Guide des arbres et arbustes de la région de Kinshasa - Brazzaville. Jardin Botanique National de Belgique, Meise.

PAX, F., 1888, Beiträge zur Kenntnis der Capparidaceae. Bot. Jahrb. Syst., 9, 39-69. 
PAyER, J. B., 1857, Traité d'organogénie comparée de la fleur. Paris.

RAMA DEVI, D., 1991, Floral anatomy of Hypseocharis (Oxalidaceae) with a discussion on its systematic position. Pl. Syst. Evol., 177, 161-164.

RAO, A. N., 1962, Floral anatomy and gametogenesis in Hopea racophloea Dyer. J. Indian Bot. Soc., 41, $557-562$

REED, C. F., 1955, The comparative morphology of the Olacaceae, Opiliaceae and Octoknemaceae. Mem. Soc. Broteriana, 10, 29--79.

Roels, P.; SMETS, E. F., 1994, A comparative floral ontogenetical study between Adoxa moscharellina and Sambucus ebulus. Belg. J. Bot., 127, $157-170$.

Ronse Decraene, L. P.; Akeroyd, J., 1988, Generic limits in Polygonum and related genera (Polygonaceae) on the basis of floral characters. Bot. J. Linn. Soc., 98, 321-371.

Ronse Decraene, L. P.; Smets, E., 1987, The distribution and the systematic relevance of the androecial characters oligomery and polymery in the Magnoliophytina. Nord. J. Bot., 7, 239-253.

Ronse Decraene, L. P.; Smets, E., 1990a. The floral development of Popowia whitei (Annonaceae). Nord. J. Bot., 10, 411-420 [Correction in Nord. J. Bot. 11, 420, 1991].

Ronse Decraene, L. P.; Smets, E., 1990b, The systematic relationship between Begoniaceae and $\mathrm{Pa}$ paveraceae: a comparative study of their floral development. Bull. Jard. Bot. Natl. Belg., 60, 229273.

Ronse Decraene, L. P.; SMETS, E., 1991 a, Morphological studies in Zygophyllaceae I. The floral development and vascular anatomy of Nitraria retusa. Amer. J. Bot., 78, 1438-1448.

Ronse Decraene, L. P.; SMETS, E., 1991 b, The floral ontogeny of some members of the Phytolaccaceae (subfamily Rivinoideae) with a discussion of the evolution of the androecium in the Rivinoideae. Biol. Jaarb. Dodonaea, 59, 77-99.

Ronse DeCRaEne, L. P.; SMets, E., 1991 c, The impact of receptacular growth on polyandry in the Myrtales. Bot. J. Linn. Soc., 105, 257-269.

Ronse Decraene, L. P.; Smets, E., 1992, An updated interpretation of the androecium of the Fumariaceae. Can. J. Bot., 70, 1765-1776.

Ronse Decraene, L. P.; Smets, E., 1993a, Dédoublement revisited: towards an improved interpretation of the androecium of the Magnoliophytina. Bot. J. Linn. Soc., 113, 103-124.

Ronse Decraene, L. P.; Smets, E., 1993b, The distribution and systematic relevance of the androecial character polymery. Bot. J. Linn. Soc., 113, 285350.

Ronse Decraene, L. P.; Smets, E., 1994, Merosity in flowers: definition, origin and taxonomic significance. Pl. Syst. Evol., 191, 83- 104.
Ronse Decraene, L. P.: Smets, E., 1995a, The androecium of Monocotyledons. In: Monocotyledons: systematics and evolution/ed. by P. J. RUDALL, P. CRIBB, D. F. CUTLER and C. J. HUMPHRIES, 243-254. Royal Botanic Gardens, Kew.

Ronse DeCraene, L. P.; Smets, E., 1995b, The distribution and systematic relevance of the androecial character oligomery. Bot. J. Linn. Soc., 118, 193 to 247.

Ronse DeCraene, L. P.; De Laet, J.; SMeTs, E., 1996, Morphological studies in Zygophyllaceae. II. The floral development and vascular anatomy of Peganum harmala. Amer. J. Bot. 83, 201-205.

SATTLER, R.; SinGH, V., 1978, Floral organogenesis of Echinodorus amazonicus Rataj and floral construction of the Alismatales. Bot. J. Linn. Soc., 77, $141-156$

SAUNDERS, E. R., 1939, Floral morphology, a new outlook, with special reference to the interpretation of the gynoecium. Vol. 2. Cambridge.

SCHÖFFEL, K., 1932. Untersuchungen über den Blütenbau der Ranunculaceen. Planta, 17, 315-371.

SLEUMER, H., 1935, Olacaceae. In: Die natürlichen Pflanzenfamilien, 2nd ed./ed. by A. ENGLER and K. PrantL. Vol. 16b, 5-32. Leipzig.

SMiтн, C. M., 1929, Development of Dionaea muscipula I. flower and seed. Bot. Gaz. 87, 507 to 530.

STERN, K., 1917, Beiträge zur Kenntnis der Nepenthaceae. Flora, 109. 213-282.

ThORNe, R. F., 1977, Some realignments in the Angiospermae. PI. Syst. Evol. (Supp.), 1, 299-319.

Tillson, A. H.; BAmFord, R., 1938, The floral anatomy of the Aurantioideae. Amer. J. Bot., 25, 780793.

TROLL, W., 1956, Die Urbildlichkeit der organischen Gestaltung und Goethes Prinzip der "Variabelen Proportionen". Neue Hefte zur Morphologie, 2, 64-76.

TUCKER, S. C., 1981, Inflorescence and floral development in Houttuynia cordata (Saururaceae). Amer. J. Bot., 68, 1017-1032.

TUCKER, S. C., 1985, Initiation and development of inflorescence and flower in Anemopsis californica (Saururaceae). Amer. J. Bot., 72, 20-31.

TuCKer, S. C.; Douglas, A. W.; Liang, HaN-XING, 1993. Utility of ontogenetic and conventional characters in determining phylogenetic relationships of Saururaceae and Piperaceae (Piperales). Syst. Bot., 18, 614-641.

UPHOF, J. C. T., 1936, Sarraceniaceae. In: Die natürlichen Pflanzenfamilien, 2nd ed./ed. by A. ENGLER and K. PRANTL. Vol. 17b, 704-727. Leipzig.

URBAN, I., 1892, Blüthen- und Fruchtbau der Loasaceen. Ber. Deutsch. Bot. Ges., 10, 259-265.

Van Tieghem, P., 1897, Sur les Buxacées. Ann. Sci. Nat. Bot., 8 (5), 289-338. 
Venkata RaO, C., 1952, Floral anatomy of some Malvales and its bearing on the affinities of families included in the order. J. Indian Bot. Soc., 31, $171-203$.

Venkata Rao, C.: Ramalakshmi, T., 1968, Floral anatomy of Euphorbiaceae I. some non-cyathium taxa. J. Indian Bot. Soc., 47, 278-298.

ZOHARY, M.; BAUM, B., 1965, On the androecium of Tamarix flower and its evolutionary trends. Isr. J. Bot., 14, 101-111.
Address of the authors:

Dr. L. P. Ronse Decraene, Prof. Dr. E. Smets, Laboratory of Systematics, Botanical Institute, Katholieke Universiteit Leuven, Kardinaal Mercierlaan 92, B-3001 Leuven, Belgium.

Manuscript received: October, 20th, 1995. 